\title{
Worldwide shale-oil reserves: towards a global approach based on the principles of Petroleum System and the Petroleum System Yield ${ }^{\star}$
}

\author{
Marc Blaizot ${ }^{1,2, *}$ \\ 1 SGF, Paris, France \\ 2 TOTAL SA, Paris, France
}

\begin{abstract}
Global inventory of shale-oil resources and reserves are far from being complete even in mature basins which have been intensively drilled and produced and in which the main parameters of the regional or local oil-prone source rocks are known. But even in these cases, difficulties still occur for deriving reserves from resources: reaching a plausible recovery factor is actually a complex task because of the lack of production history in many shale-oil ventures. This exercise is in progress in several institutions (EIA, USGS, AAPG) or private oil and gas companies on a basin-by-basin basis in order to estimate the global potential. This analytical method is very useful and accurate but also very time consuming. In the last EIA report in 2013 "only" 95 basins had been surveyed whereas for example, no Middle-East or Caspian basins have been taken into account. In order to accelerate the process and to reach an order of magnitude of worldwide shale-oil reserves, we propose hereafter a method based on the Petroleum System principle as defined by Demaison and Huizinga (Demaison G and Huizinga B. 1991. Genetic classification of Petroleum Systems. AAPG Bulletin 75 (10): 1626-1643) and more precisely on the Petroleum System Yield (PSY) defined as the ratio (at a source-rock drainage area scale) between the accumulated hydrocarbons in conventional traps (HCA) and hydrocarbons generated by the mature parts of the source-rock (HCG). By knowing the initial oil reserves worldwide we can first derive the global HCA and then the HCG. Using a proxy for amount of the migrated oil from the source-rocks to the trap, one can obtain the retained accumulations within the shales and then their reserves by using assumptions about a possible average recovery factor for shale-oil. As a definition of shale-oil or more precisely LTO (light tight oil), we will follow Jarvie (Jarvie D. 2012. Shale resource systems for oil \& gas: part 2 - Shale Oil Resources Systems. In: Breyer J, ed. Shale Reservoirs. AAPG, Memoir 97, pp. 89-119) stating that "shale-oil is oil stored in organic rich intervals (the source rock itself) or migrated into juxtaposed organic lean intervals". According to several institutes or companies, the worldwide initial recoverable oil reserves should reach around $3000 \mathrm{Gbo}$, taking into account the already produced oil (1000 Gbo) and the "Yet to Find" oil (500 Gbo). Following a review of more than 50 basins within different geodynamical contexts, the world average PSY value is around 5\% except for very special Extra Heavy Oils (EHO) belts like the Orinoco or Alberta foreland basins where PSY can reach 50\% (!) because large part of the migrated oils have been trapped and preserved and not destroyed by oxidation as it is so often the case. This $50 \%$ PSY figure is here considered as a good proxy for the global amount of expelled and migrated oil as compared to the HCG. Confirmation of such figures can also be achieved when studying the ratio of S1 (in-place hydrocarbon) versus S2 (potential hydrocarbons to be produced) of some source rocks in Rock-Eval ${ }^{1}$ laboratory measurements. Using $3000 \mathrm{Gbo}$ as worldwide oil reserves and assuming a quite optimistic average recovery factor of $40 \%$, the corresponding HCA is close to $7500 \mathrm{Gbo}$ and $\mathrm{HCG}$ (= HCA/PSY) close to $150000 \mathrm{Gbo}$. Assuming a $50 \%$ expulsion (migration) factor, we obtain that $75000 \mathrm{Gbo}$ is trapped in source-rocks worldwide which corresponds to the shale-oil resources. To derive the (recoverable) reserves from these resources, one needs to estimate an average recovery factor (RF). Main parameters for determining recovery factors are
\end{abstract}

\footnotetext{
^ Conférence SGF 26 et 27 novembre 2015; Les roches mères pétrolières

*Corresponding author: marc.blaizot@laposte.net

${ }^{1}$ Vinci Technologies trade mark
} 
reasonable values of porosity and saturation which is difficult to obtain in these extremely fine-grained, tight unconventional reservoirs associated with sampling and laboratories technical workflows which vary significantly. However, new logging technologies (NMR) as well as SEM images reveal that the main effective porosity in oil-shales is created, thanks to maturity increase, within the organic matter itself. Accordingly, porosity is increasing with Total Organic Carbon (TOC) and paradoxically with... burial! Moreover, porosity has never been water bearing, is mainly oil-wet and therefore oil saturation is very high, measured and calculated between 75 and $90 \%$. Indirect validation of such high figures can be obtained when looking at the first vertical producing wells in the Bakken LTO before hydraulic fracturing started which show a very low water-cut (between 1 and $4 \%$ ) up to a cumulative oil production of $300 \mathrm{Kbo}$. One can therefore assume that the highest RF values of around $10 \%$ should be used, as proposed by several researchers. Accordingly, the worldwide un-risked shale-oil reserves should be around 7500 Gbo. However, a high risk factor should be applied to some subsurface pitfalls (basins with mainly dispersed type III kerogen source-rocks or source rocks located in the gas window) and to many surface hurdles caused by human activities (farming, housing, transportation lines, etc...) which can hamper developments of shale-oil production. Assuming that only shale-oil basins in (semi) desert conditions (i.e., mainly parts of Middle East, Kazakstan, West Siberia, North Africa, West China, West Argentina, West USA and Canada, Mexico and Australia) will be developed, a probability factor of $20 \%$ can be used. Accordingly, the global shale-oil reserves could reach 1500 Gbo which is half the initial conventional reserves and could therefore double the present conventional oil remaining reserves.

Résumé - Les réserves mondiales de pétrole non-conventionnel (shales-oils): pour une approche mondiale fondée sur le système pétrolier et le PSY (Petroleum System Yield). L'inventaire mondial des ressources et réserves en huile de schistes ou huile de roches mères, est loin d'être achevé même dans les bassins pétroliers matures qui ont été largement forés et produits et dans lesquels les paramètres principaux des roches mères à huile sont bien connus. Même dans ce type de bassins, il reste difficile de passer des ressources aux réserves car atteindre l'ordre de grandeur des facteurs de récupération est un travail complexe $\mathrm{du}$ fait du manque d'historique de production des champs actuels d'huile de schistes. Ce travail d'inventaire et d'estimations des réserves est en cours dans quelques institutions publiques (USGS, AAPG, EIA) ou compagnies pétrolières privées sur une base analytique, bassin par bassin et pour certains, roche mère par roche mère. Cette méthode est précise mais nécessite de beaucoup de temps : dans son dernier rapport sur le sujet (2013), l'EIA indiquait qu'elle n'avait pu étudier que 95 bassins au total sans prendre en compte aucun des bassins pétroliers situés au Moyen Orient ou autour de la Caspienne! Pour accélérer ce processus d'évaluation et obtenir un ordre de grandeur des réserves en huile de schistes, nous proposons ici une méthode fondée sur le concept du Système pétrolier comme défini par Demaison and Huizinga (Demaison $\mathrm{G}$ and Huizinga B. 1991. Genetic classification of Petroleum Systems. AAPG Bulletin 75 (10): 1626-1643) et plus spécifiquement sur le Petroleum System Yield (PSY) défini comme le rapport (à l'échelle de l'aire de drainage d'une roche mère) entre les accumulations d'hydrocarbures piégés dans les gisements conventionnels (HCA) et les hydrocarbures totaux générés (HCG) par les roches matures. En sachant les réserves initiales mondiales des gisements conventionnels, on peut déterminer le HCA et par application d'un PSY moyen, le HCG. En utilisant une approximation sur l'importance des pertes de migration de la roche mère aux accumulations, on peut obtenir le montant des hydrocarbures retenus dans les roches mères c'est-à-dire le montant mondial des accumulations d'huiles de schistes puis par application d'un coefficient de récupération moyen, les réserves potentielles. Nous utiliserons ici comme définition d'huiles de schistes (ou LTO pour Light Tight Oil) celle de Jarvie (Jarvie D. 2012. Shale resource systems for oil \& gas: part 2 - Shale Oil Resources Systems. In: Breyer J, ed. Shale Reservoirs. AAPG, Memoir 97, pp. 89-119) indiquant que «les huiles de schistes sont les huiles accumulées dans des intervalles riches en matière organique (la roche mère elle-même), ou migrées dans des intervalles adjacents, à faible teneur en matière organique ». Selon plusieurs instituts ou compagnies, les réserves mondiales de pétrole conventionnel sont de l'ordre de $3000 \mathrm{~Gb}$ d'huile en prenant en compte ce que nous avons déjà produit (1000 Gbo) et ce qu'il reste à découvrir ( $500 \mathrm{Gbo})$. Après une revue de plus de 50 bassins situés dans des contextes géodynamiques variés, la valeur du PSY moyen mondial est proche de $5 \%$ à l'exception des ceintures bitumineuses des bassins, riches en huiles lourdes, de l'Orénoque (Venezuela) et de l'Alberta (Canada) où les PSY peuvent atteindre $50 \%$ ! Ces deux anomalies sont à mettre en relation avec le fait que dans ces deux bassins, les produits migrés ont été piégés et préservés de la destruction par oxydation comme c'est très souvent la règle. En conséquence, nous considérerons que ce chiffre de $50 \%$ est une bonne approximation pour connaître le montant total de produits expulsés (migrés et accumulés) d'une roche mère mature par rapport à son HCG. Une confirmation peut être obtenue à l'échelle de l'échantillon en comparant les valeurs de S1 (hydrocarbures présents) et de S2 (hydrocarbures productibles) fournis par diverses mesures Rock-Eval sur roches mères. En utilisant nos 3000 Gbo comme réserves mondiales de pétrole et en utilisant pour cette démonstration un facteur de récupération des réservoirs conventionnels de $40 \%$, on obtient un HCA 
d'environ 7500 Gbo et un HCG (=HCA/PSY) de 150000 Gbo. En faisant l'hypothèse d'un facteur d'expulsion moyen de $50 \%$, on obtient qu'environ 75000 Gbo est piégé à l'intérieur des roches mères à l'échelle de l'ensemble des bassins sédimentaires du monde, synonyme de l'ensemble des ressources probables d'huile de schistes. Pour estimer les réserves à partir de ces ressources, il faut à la fois appliquer un facteur de récupération (RF) et un facteur de risques (toutes les roches mères ne sont pas exploitables). Les paramètres principaux pour déterminer le facteur de récupération sont la porosité et la saturation qui sont très difficiles à mesurer dans ces roches extrêmement compactes sur lesquelles les résultats laboratoires varient de manière significative en fonction des protocoles et techniques utilisés. Cependant, les nouveaux outils de logging (NMR) ainsi que les images obtenues par microscopie électronique (MEB) révèlent que la porosité principale est créée par l'augmentation de maturité à l'intérieur même de la matière organique. En conséquence, la porosité augmente d'une part avec la teneur en carbone (COT) et d'autre part, de manière paradoxale, avec... l'enfouissement. De plus, cette porosité n'a jamais été imbibée d'eau, est principalement mouillable à l'huile et la saturation en huile mesurée est extrêmement haute située entre 75 et $90 \%$. Les premiers puits, forés verticalement et complétés sans fracking hydraulique, de la Bakken Formation, valident de manière indirecte ces hautes saturations, affichant des teneurs en eau très basses (entre 1 et $4 \%$ de water-cut) même après plus de 300 Kbo de production cumulée. On peut probablement alors accepter des valeurs de $10 \%$ de facteur de récupération comme proposées par plusieurs auteurs. En conséquence, les réserves non risquées d'huile de schistes seraient d'environ $7500 \mathrm{Gbo}$. Cependant, un facteur de risque très important doit être appliqué du fait des conditions géologiques (bassins avec des matières organiques de type III ou avec des roches mères situées dans la fenêtre à gaz), géographiques (bassins sous-marins) et surtout des conditions économiques et humaines (agriculture, habitat, routes, etc...) qui empêcheront de facto tout développement de gisements d'huile de schistes. En supposant donc que c'est seulement dans les bassins situés dans des conditions semi-désertiques (par exemple, le Moyen Orient, le Kazakstan, la Sibérie Occidentale, l'Afrique du Nord, la Chine occidentale, les bassins de piémont argentins, l'Ouest des ÉtatsUnis et du Canada, le Mexique et l'Australie) que les gisements d'huiles de schistes pourraient être à terme développés, une probabilité de succès de $20 \%$ a été utilisée. En conséquence, les réserves mondiales d'huiles de schistes pourraient être proches de 1500 Gbo soit la moitié des réserves conventionnelles initiales et pourraient faire doubler les réserves conventionnelles connues actuelles.

\section{Introduction}

A conference on source rocks cannot ignore the potential of oil production from source rocks, so called shale-oil, which since a few years surprisingly makes up a significant part of US liquid oil production, increasing between 2010 and 2014 from zero to $3 \mathrm{MMbpd}$. This is not an insignificant part of world oil production which has reached 94 MMbpd on average in 2014 and should reach 97 MMbpd in 2015 (Fig. 1).

In this article, we try to estimate the world-wide oil reserves from source rocks using the notion of generation potential of source rocks which is relatively well understood, as well as their retention capacity (or non-expulsion) which is less understood. Various empirical and geochemical approaches from the basin to the laboratory scale will be used to determine the retention potential of source rocks. We will also try to estimate a recovery factor for these retained fluids using analogues of petrographical, geomechanical and fluid characteristics from US shales. A recovery factor is difficult to know because little production data are available beyond the short production history of these unconventional reservoirs. Nevertheless, their production demonstrates a surprising production resilience due to the large number of wells and the possibility of refracking but also due to the better than thought petrophysical properties.

Unconventional oil (or LTO = light tight oil) is defined here in accordance with Jarvie (2012) as oil that is generated by rock formations rich in organic matter that are oil - mature and trapped either within the source rock layers or in its immediate vicinity (not more than a few meters of migration within such an extremely low permeability rock matrix). These oils did not experience secondary migration and stay in these compact reservoirs and therefore are not limited by a water-oil contact.

\section{Oil in source rocks: how is it retained}

A first estimate of the quantity of oil trapped in source rocks has been done by P.K. Meyer in a short article in the Oil and Gas Journal in May 2012. He makes an intriguing and almost shocking statement that within a source rock, retained oil makes up about $80 \%$ of generated oil. When comparing the recovery factor of oil from source rocks and conventional reservoirs, P.K. Meyer estimates that the amount of recoverable oil (or oil reserves) is eight times greater in source rocks than in conventional reservoirs!

This is very different from what the conventional wisdom of petroleum geology has taught us since the 1980s on both sides of the Atlantic (see Magoon, 1988; Demaison and Huizinga, 1991; Perrodon, 1995). The seminal article by W. England in the famous AAPG Memoir 60 (1994) did not even mention $\mathrm{HC}$ retention, if it is not synonymous with "loss to primary migration" which he considered about $15 \%$ of the generated oil (Fig. 2). In his model, the majority of oil (60\%) is indeed lost during migration whereas only a small amount $(8 \%)$ is trapped in commercial (conventional) accumulations, either structurally or stratigraphically. This percentage also corresponds to the sum of all conventionally trapped hydrocarbons in producing reservoirs (HCA). Yet another way to calculate this percentage is to estimate it from the petroleum potential of basins (HCG), combining amount of organic 


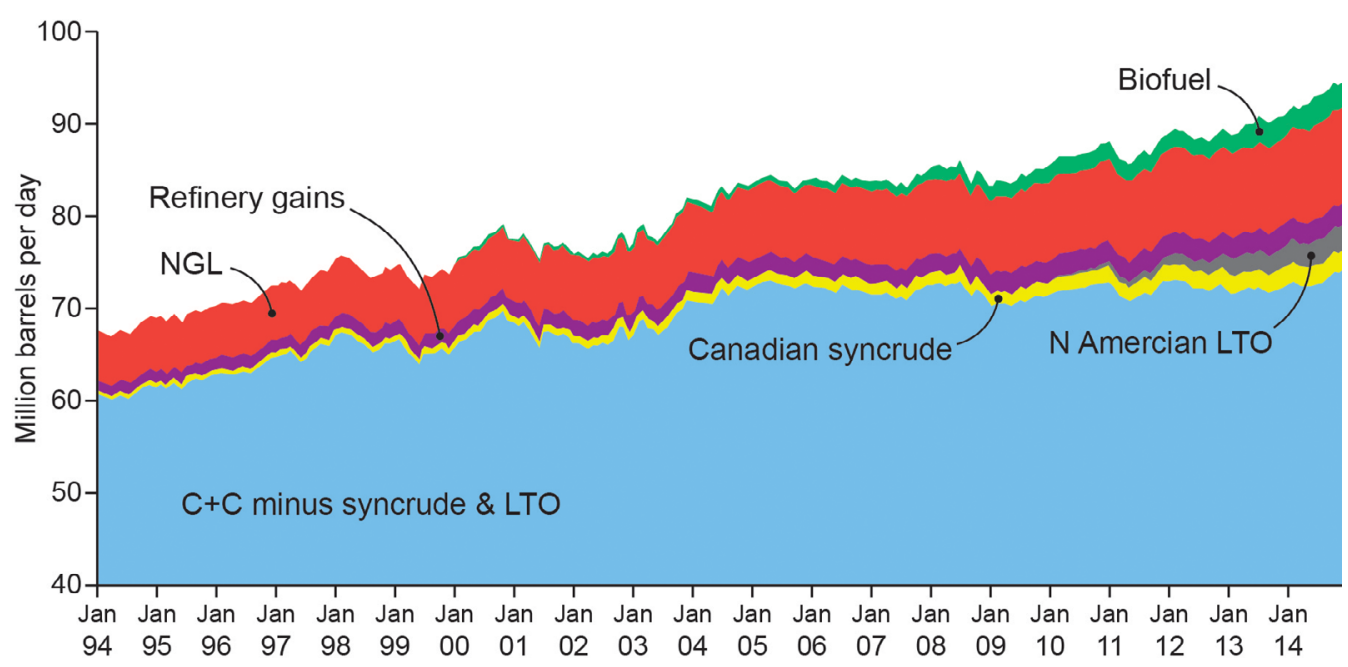

Fig. 1. Recent (2010) and unexpected US LTO production, from 1994 to 2014 from "Energy Matters" by euanmearns.com.

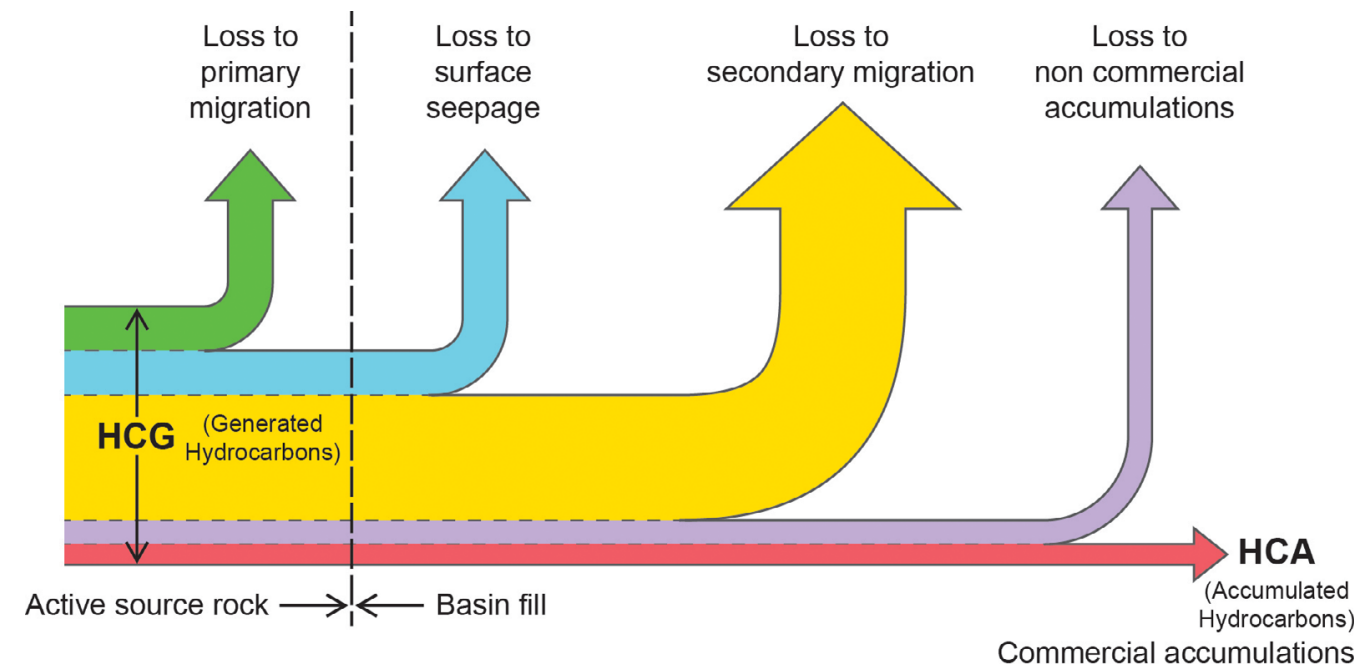

Fig. 2. Classical assumptions for migration and accumulation; after England W., AAPG Memoir 60, 1994.

matter originally contained in source rocks and their state of maturity.

For a given source rock and a given drainage area, HCG can be calculated according to Demaison and Huizinga (1991) using the following formula:

$\mathrm{HCG}=\mathrm{h} \times(\mathrm{S} 1+\mathrm{S} 2) \times$ Density $\times \mathrm{TR} \times$ Drainage area

Parameters S2 (producible hydrocarbons or hydrogen index) and S1 (free in situ hydrocarbons or hydrocarbon index) are expressed in $\mathrm{mg} \mathrm{HC/g} \mathrm{TOC.} \mathrm{S2} \mathrm{corresponds} \mathrm{to}$ total hydrocarbons that could be generated from a source rock if all its potential is realized (i.e., its transformation ratio $\mathrm{TR}=100 \%$ ) while $\mathrm{S} 1$ corresponds to hydrocarbons present in the source rock that had already been generated but are retained in the source rock. S1 is oftentimes underestimated because a large part is lost before its actual measurement, as already and perfectly stated by Price and LeFever (1992). Nevertheless, S1 can be a used as a proxy for a retention coefficient.
Once HCG is determined for all source rocks in a basin, it can be compared with HCA mainly in basins that are already highly explored, with important historical production where accumulations (oil in place) are generally well-known. Such results have been published by Biteau et al. (2010) (Fig. 3) for more than 60 basins in various structural and geodynamical settings. The ratio of HCA/HCG or petroleum systems yield (PSY) of these basins is between 1 and $10 \%$, with an average of less than 5\% (Fig. 5). Only the Alberta and Orinoco basins show an exceptionally high PSY of 50\%! Both these basins contain large amounts of bituminous oils (or Extra Heavy oils) at shallow depths that are preserved at the fringes of these basins after have migrated long distances and having been trapped by topographic driven hydrodynamics. Therefore, these two basins are rare cases where the amount of migrated oil is preserved while normally a large amount of migrated oil is lost, both for explorers and scientists alike. If this is the case, we can estimate the amount of migrated oil at $45-50 \%$ of HCG. 


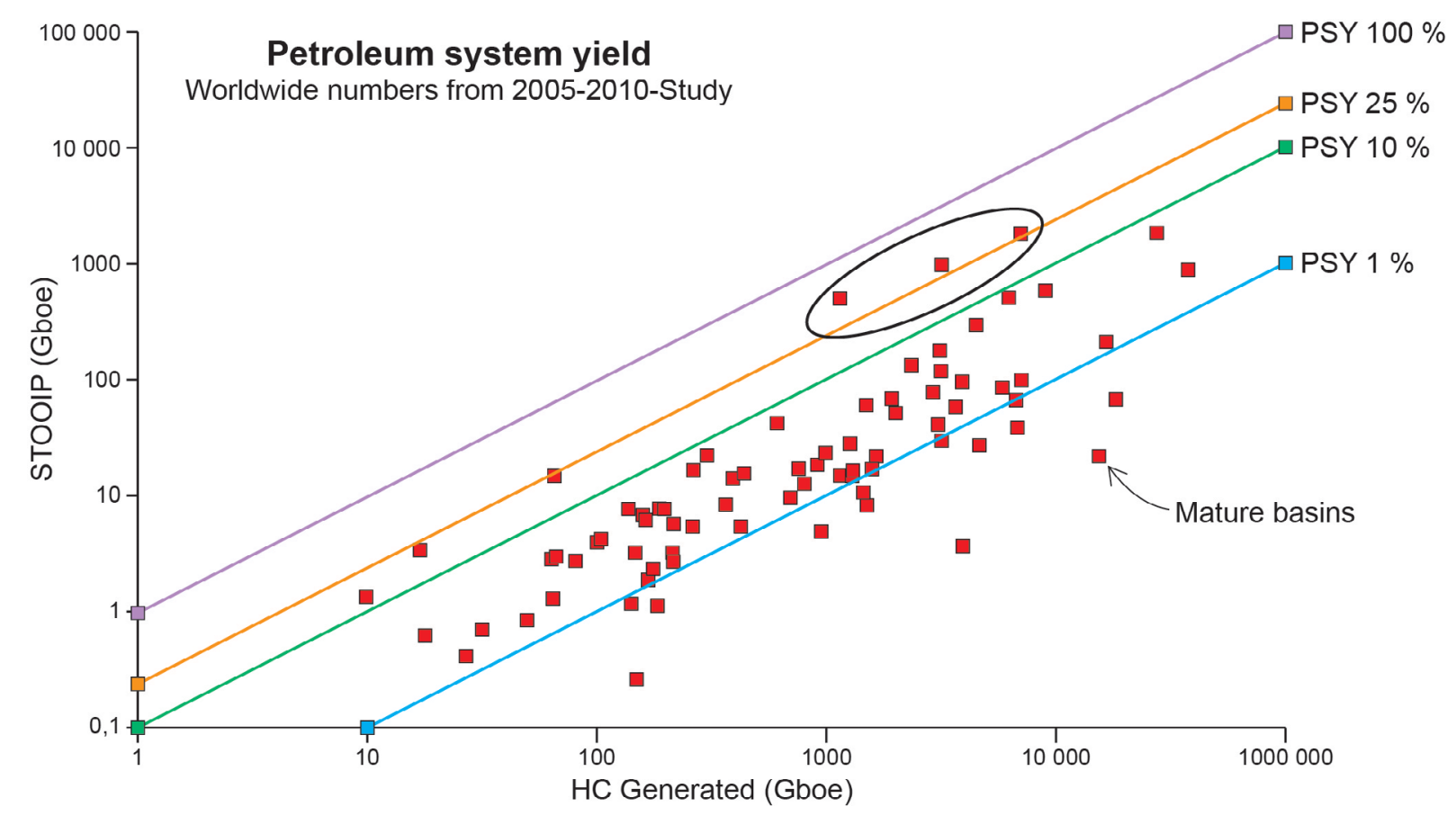

Fig. 3. PSY values for mature basins modified from Biteau JJ., First Break, EAGE, November 2010.

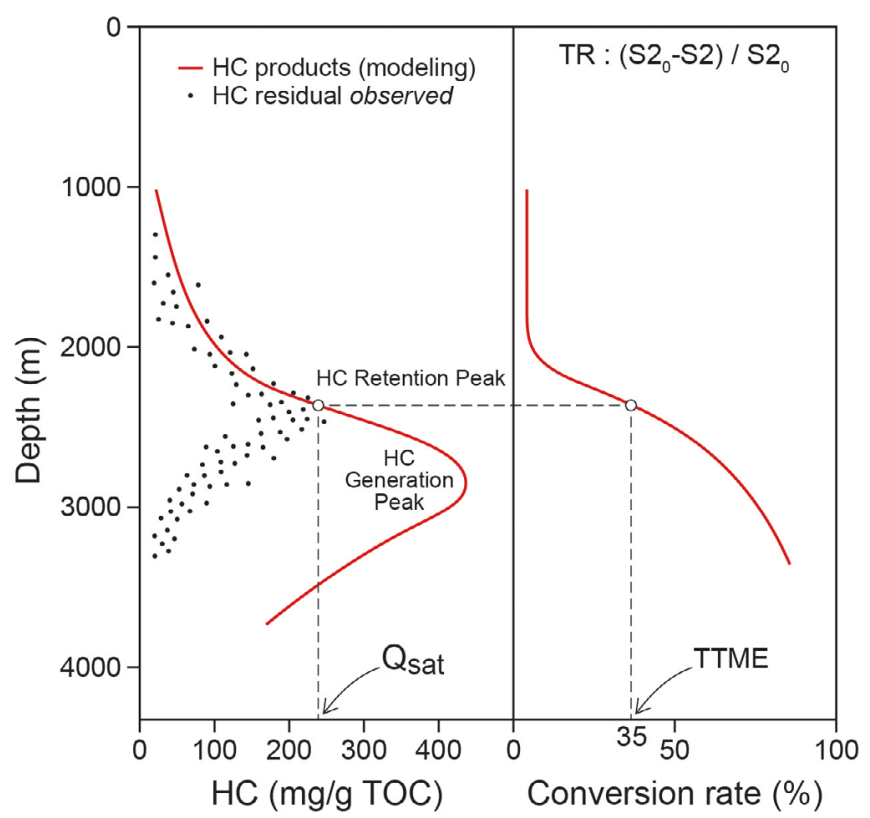

Fig. 4. The retention ratio modified from Espitalié et al. (1985).

This also means that the amount of retained oil must be the remainder, around 50\%. With this number we are much closer to the number published by Meyer (2012) than the numbers conventionally used (15\%).

Another way to determine the amount of retention in source rocks is to measure in the laboratory the amount of HCs present in source rocks. Several studies by Espitalié et al. (1985) (Fig. 4) or Jarvie (2012) indicate very high numbers of S1 (free hydrocarbons) close to $250 \mathrm{mg} \mathrm{HC} / \mathrm{g}$ TOC and ratios of $\mathrm{S} 1 / \mathrm{S} 2$ near $35 \%$ which is not far away from our hypothesis of $50 \%$.

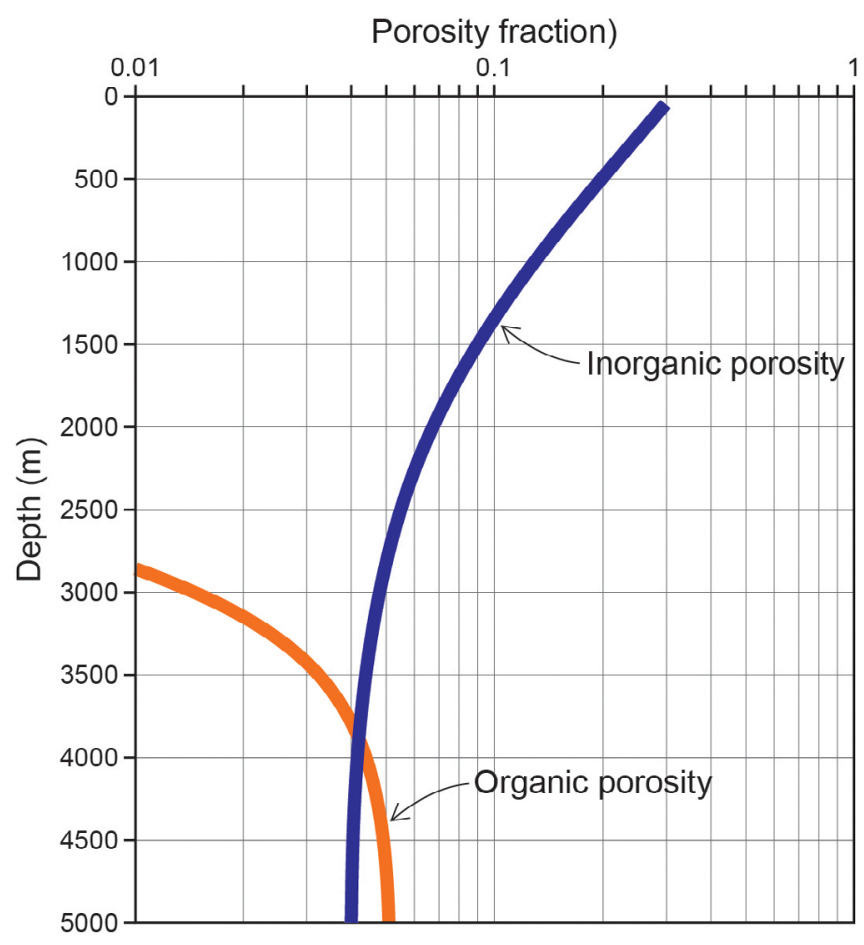

Fig. 5. Porosity within Shales: Eagle Ford Example from Cander H., AAPG annual convention, April 2012.

A complete geochemical analysis of the Lower and Upper Bakken shales (Zhang et al., 2013) shows that no significant petroleum expulsion is observed in the center of the Upper and Lower Bakken. This shows that retention is indeed very important in shales even if it is certainly less near the Middle 


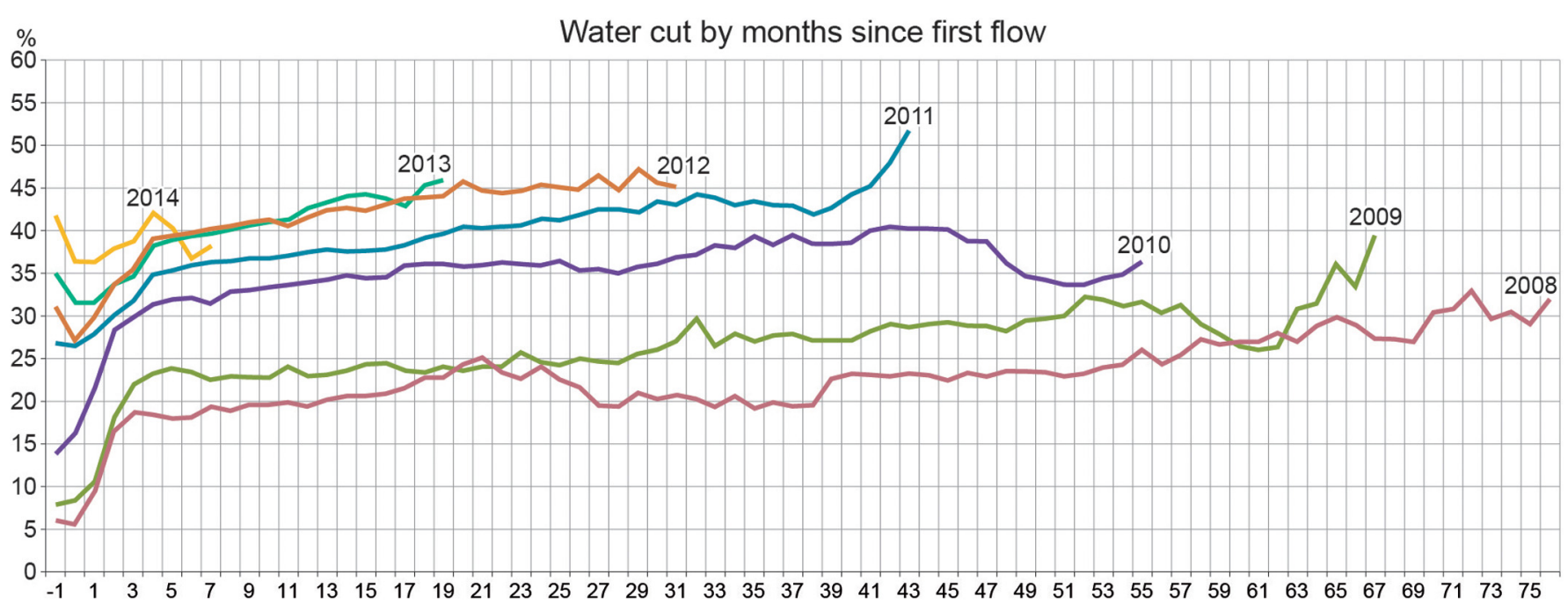

Fig. 6. Oil saturation in shale-oils: water production in the Bakken, from: http://fractionalflow.com posted by Rune Likvern, December 2014.

Bakken whose lithology is less shaly and therefore acts more like a drain towards the under- and overlying oil-rich shales.

\section{Shale-oil reserves: how much recovery}

As indicated in the introduction, the recovery factor of shale-oil is not well-known because it is difficult to measure the oil and water saturations of these highly compact rocks with very short production histories. We need first to determine its porosity if we want to estimate oil saturation and then try to quantify initial water content and its evolution during production.

While the compaction law indicates that porosity of the mineral matrix decreases during burial, the organic porosity which is located within the organic material is not a function of burial. Porosity measurements in core material and porosity visualizations based on MEB and SEM photographs show that this intra-kerogen porosity develops at the beginning of maturation and increases with maturity and therefore increases with burial. Therefore, thermal maturation of kerogen not only generates hydrocarbons but also creates porosity. Figure 5 from Cander (2012) shows the evolution with burial of the porosity of the Eagleford shale in Texas, an LTO of Upper Cretaceous age. Organic porosity reaches $5 \%$ around $5000 \mathrm{~m}$ depth where it is greater than the porosity of the mineral matrix. This porosity is a function of the amount of organic matter whose volume may reach $5-20 \%$ of the bulk rock volume for a TOC ranging from $2-8 \%$, given a mineral matrix density of $2.6 \mathrm{~g} / \mathrm{cm}^{3}$ and an organic matter density of $1.1-1.2 \mathrm{~g} /$ $\mathrm{cm}^{3}$. The oil is mainly present within this intra-kerogen organic porosity where oil saturation must be very high because this porosity is created at a later stage, during oil generation and never underwent any saturation by connate water like every classical sedimentary reservoir rock. Possible water connectivity may only be created once hydraulic fracturing occurred. In addition, the organic material is oil-wet (Rylander et al., 2013; Passey et al., 2010). Laboratory data confirm the hypothesis that oil saturations of LTOs are high to very high and stay high during production, much higher than during production from conventional reservoirs. These latter are already aquifers before oil migrates and accumulates and therefore these reservoirs always contain a significant amount of residual water which increases during production because water is replacing the produced oil either coming from the active aquifer itself or from water injection.

The few oil saturation data published in the literature indicate values of $75-90 \%$ for the Bakken shale (Philips et al., 2007) whereas Zhang et al. give a mean residual oil saturation of $40 \%$. Using an $\mathrm{S} 1$ of $10-15 \mathrm{mg} \mathrm{HC} / \mathrm{g}$ rock for the Lower and Upper Bakken, an average porosity of $8 \%$, an average TOC of $10 \%$ (which yields a bulk rock density of $2.6 \mathrm{~g} / \mathrm{cm}^{3}$ according to Passey et al., 2010) and an in situ HC density of $0.6 \mathrm{~g} / \mathrm{cm}^{3}$, we can calculate oil saturations between $50-75 \%$. This means that $1 \mathrm{~g}$ of rock corresponds to $0.38 \mathrm{~cm}^{3}$ or to $0.03 \mathrm{~cm}^{3}$ of pore volume or $0.018 \mathrm{~g}$ of $\mathrm{HC} / \mathrm{g}$ rock. For $\mathrm{S} 1=10 \mathrm{mg} \mathrm{HC} / \mathrm{g}$ rock, oil saturation reaches about $55 \%$ while for $\mathrm{S} 1=15 \mathrm{mg} / \mathrm{g}$, oil saturation reaches $80 \%$.

Indeed, the water cut of production of LTO is very low, as shown for example in the first vertical wells drilled without hydraulic fracturing in the 1980s into the Bakken source rock of Devonian to Carboniferous age that have a ridiculously low water production of $1-4 \%$ even after 300000 barrels of cumulative production from a single well. The water cut of horizontal wells (after frac water removal) starts at about $20 \%$ in 2008 and increases to about $30 \%$ in 2014 (see Fig. 6). The most recently drilled wells show an initial water cut of 35 $40 \%$, there is therefore a global increase of water cut during production of the field. This is probably due to the frequent fraccing operations which create ever increasing contact areas between fractures and the source rock matrix. But again, the increase in water cut during production remains moderate, increasing from 40 to $45 \%$ in two years. Saturation remains oil dominated and it is this low water fraction which is in our opinion a major reason for the resilience of production despite a drastic reduction in the number of on stream wells in 2014 due to the decrease in oil price (see Fig. 7).

The recovery factors used by the EIA in its report of 2013 which range between 2 and $8 \%$ for American shale oil should be questioned. They are given as a function of natural and 


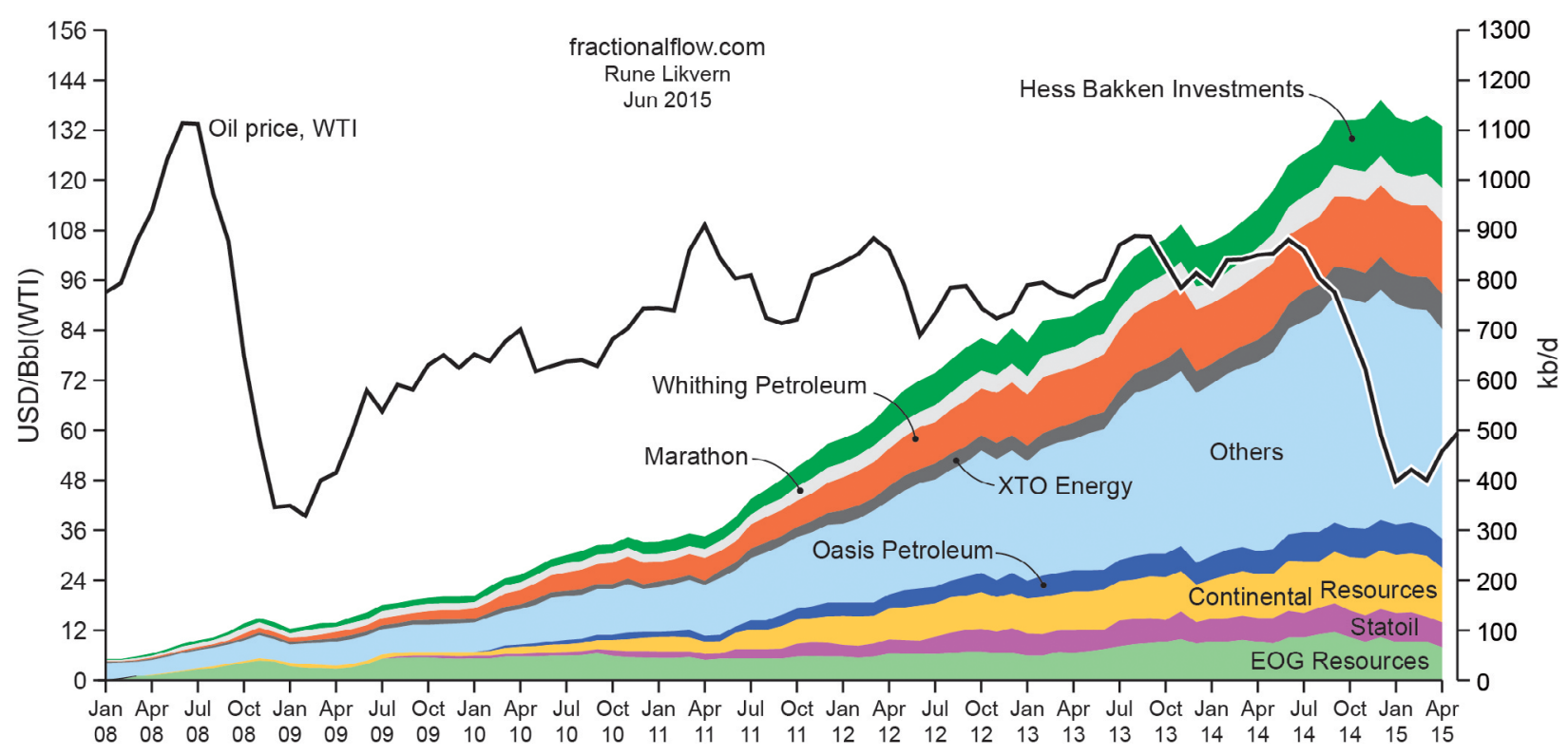

Fig. 7. Oil saturation in shales-oils: oil production in the Bakken, from: http://fractionalflow.com posted by Rune Likvern, April 2015.

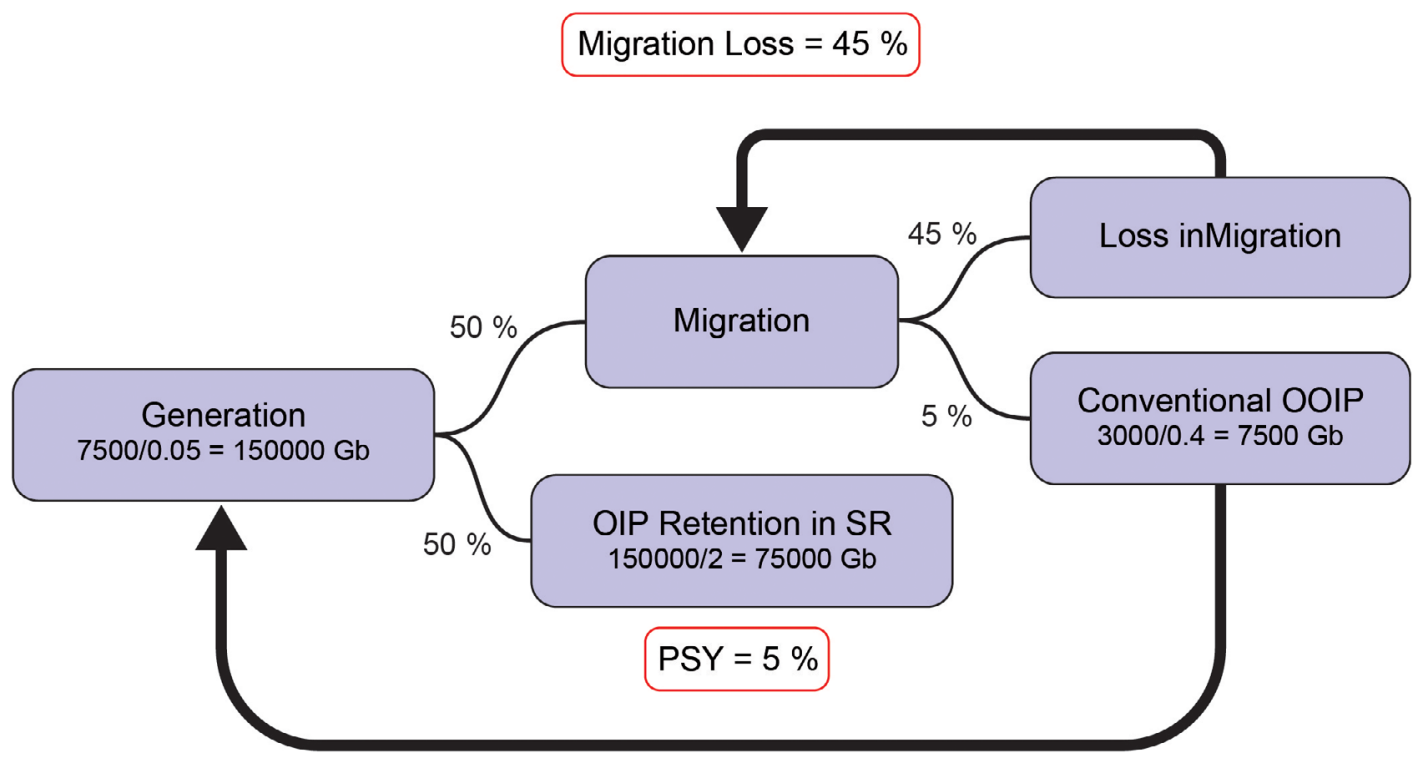

Fig. 8. A global approach to retention in Source Rocks.

induced fraccability and formation pressure but seem to totally neglect the oil saturation of the organic material. An average recovery factor of $10 \%$ seems more appropriate, given analytical laboratory results and well production data. This corresponds also to the higher value proposed by Charlez (2015).

\section{From shale-oil resources to reserves: how and where?}

If we accept a retention coefficient of $50 \%$ of generated $\mathrm{HCs}$ and estimate a recovery factor of $10 \%$ in unconventional LTO accumulations, we can calculate resources and world reserves of shale-oil. The in-place volumes of conventional oil and gas fields are fairly well-known except for the yet to find volumes: the initial world reserves are about 3000 Gbo of which 1000 have been produced and 500 are still to be discovered. Assuming a final recovery factor of $40 \%$, the total in-place volume in accumulations is $3000 / 0.4=7500$ Gbo. If these accumulations (HCA) correspond to $10 \%$ of migrated HCs which themselves correspond to $50 \%$ of generated $\mathrm{HC}$, then the total generated $\mathrm{HC}$ (HCG) is $7500 / 0.05=150000$ Gbo. Since the retained oil corresponds to $50 \%$ of the generated oil, this means that oil generated and retained in source rocks (resources) equals to 75000 Gbo (see Fig. 8).

Of course, not all source rocks of all the sedimentary basins in the world can be exploited as in the US shales (Vially, 2015) because they may have different geological 


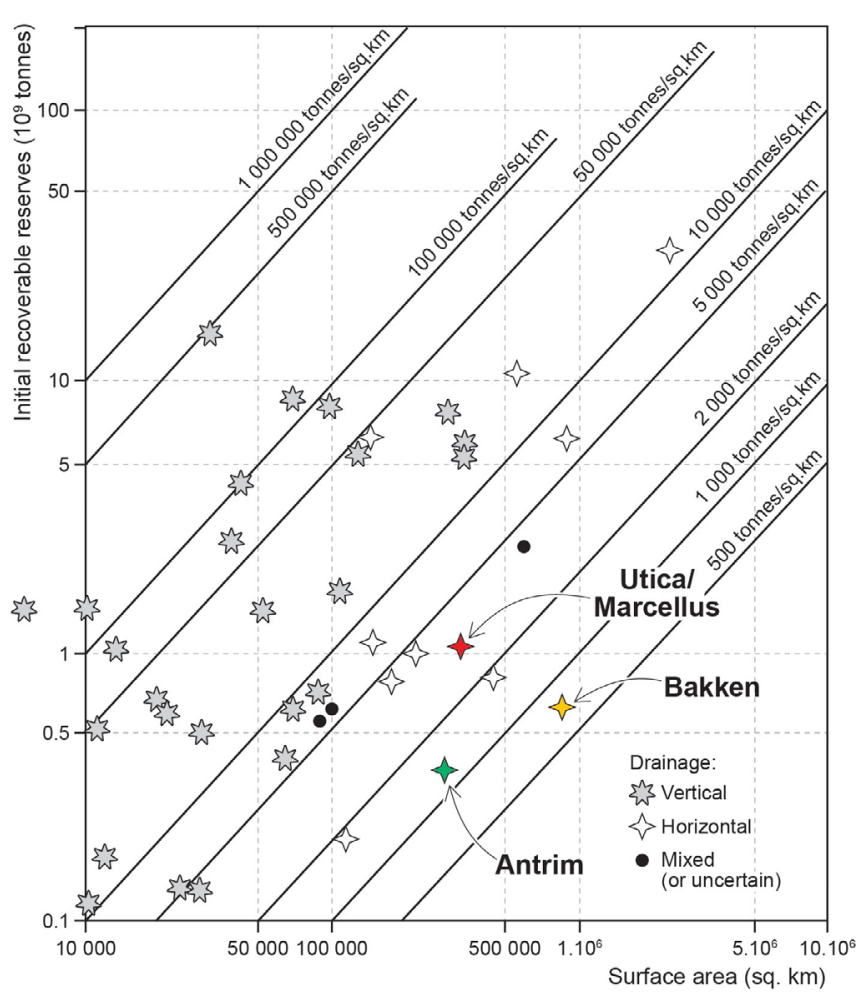

Fig. 9. Shales Oils: Where shale we look for? modified from Perrodon A., Journal of Petroleum Geology, 1995.

parameters (the nature of the source rock, particularly difficult to produce if the organic matter is dispersed as is often the case in Type III kerogen source rocks; the position of the oil window in source rocks of Type I and II kerogens; the mineralogy therefore the geomechanical properties of the source-rock that can be little or not frackable) or may be located in economically or geographically unfavorable areas for production such as highly populated areas.

Assuming that only the mature basins from a petroleum exploration point of view that are located in deserts or semideserts or in very sparsely populated areas will be exploited (such as Western Siberia, Kazakhstan, North Africa, Middle East, Western China, Andean foreland of Argentina, Australia, Western US or Canada, Appalachians of Eastern US), and assuming that only $20 \%$ of the world's source rocks (a conservative estimate) apply to these criteria, the risked resources in this case are $75000 \times 0.2=15000$ Gbo. Using a recovery factor of $10 \%$ yields about $1500 \mathrm{~Gb}$ of shale-oil reserves. This number is about half of the total initial liquid reserves of conventional oil fields or the equivalent of today's oil reserves. This result appears to be very different from the number published by the EIA in its report on shale-oil from $2013(335 \mathrm{~Gb})$. However, the EIA number only covers 95 terrestrial basins outside the Middle East and the Caspian Sea areas which contain about half of the world's initial conventional reserves, and has been determined with a recovery factor of only 5\%. By doubling the volume of source rock and using a recovery factor of $10 \%$ we arrive at a similar number $(335 \times 4=1340 \mathrm{~Gb})$.

Sedimentary basins with source rocks that are capable of retaining $\mathrm{HCs}$ are those that contain source rocks of kerogen
Type II (possibly also Type I) that are not affected by faults or salt tectonics which offer vertical pathways for migrating HCs. Such basins correspond to intracontinental basins or foreland basins. Such basins have mainly horizontal migration and drainage patterns and sometimes exhibit even topographic driven hydrodynamic flow (Perrodon, 1995) exhibited on a diagram of initial recoverable reserves versus basin surface area (see Fig. 9). It is therefore not surprising that important unconventional shale-oil and shale gas discoveries of the last few years such as the Bakken, Utica, and Marcellus shales have been precisely made in this type of basins.

\section{Further readings}

http://euanmearns.com: Energy Matters. Post by E. Mearns, December 2014.

http://fractionalflow.com: Rune Likvern posts December 2014 and April 2015.

www.eia.gov: EIA Report on Recoverable SG and SO Assessments, June 2013.

Société géologique de France: www.geosoc.fr/ressourcesenergetiques-quid.html.

\section{References}

Biteau J-J., Heidmann J-C., de Janvry GC, Chevallier B. 2010. The whys and wherefores of the SPI-PSY method for calculating the world hydrocarbon yet-to-find figures. First Break 28 (11): 53-64.

Bust V, Majid A, Oletu J, Worthington P. 2013. The petrophysics of shale gas: technical challenges and pragmatic solutions. Petroleum Geoscience 19 (2): 91-103.

Cander H. 2012. Sweet spots in oil and gas plays. Prediction of petroleum composition and reservoir pressure, AAPG Annual Convention, Long Beach.

Charlez P. 2015. La révolution du gaz et pétrole de schistes. Géologues 185: 43-45.

Demaison G, Huizinga B. 1991. Genetic classification of Petroleum Systems. AAPG Bulletin 75 (10): 1626-1643.

Espitalié J, Derroo G, Marquis F. 1985. La pyrolyse Rock-Eval et ses applications. Oil and Gas Science and Technology-Revue IFP, vol. $40, n^{\circ} 5$, pp. 563-579 et $n^{\circ} 6$, pp. 755-794.

England W. 1994. Secondary migration and accumulation of hydrocarbons. In: Maggoon L, Wallace G, eds. The Petroleum System from source to trap. AAPG, Memoire 60, part III, chapter 12, pp. 211-217.

Jarvie D. 2012. Shale resource systems for oil \& gas: part 2-Shale oil resources systems. In: Breyer J, ed. Shale reservoirs. AAPG, Memoir 97, pp. 89-119.

Magoon L. 1988. The Petroleum System - A classification scheme for research, exploration and ressource Assessment. In: Petroleum Systems of the United States. U.S. Geological Survey Bulletin 1870 , pp. 2-15.

Meyer P. 2012. Shale source rocks: a game-changer due to 8-to-1 resource potential. O\&G Journal 14: 72-73.

Michael G, Packwood J, Holba A. 2014. Determination of in situ hydrocarbons volumes in liquid rich shales plays. AAPG Search and Discovery Article \# 80365.

Noble R, Kaldi J, Atkinson C. 1977. Oil saturation in shales: application in seal evaluations. In: Surdam R, ed. AAPG, Mémoire 67, pp. 13-29. 
Passey Q, Bohacs K, Esch W, Klimentidis P, Sinha S. 2010. From Oilprone source to gas-producing shale reservor. SPE Paper 131350, 2010; International Oil \& Gas Conference in China, Beijing.

Perrodon A. 1980. Géodynamique pétrolière : genèse et répartition des gisements d'hydrocarbures. Masson , 2 édition, 1985, 381 p.

Perrodon A. 1995. Petroleum Systems and Global Tectonics. Journal of Petroleum Geology 18 (4): 471-476.

Philips Z, Halverson R, Strauss S, Laymon J, Green T. 2007. A case study in the Bakken Formation. Paper SPE 108045, 2007, SPE Rocky Mountain Oil and Gas Technology Symposium, denver, CO., USA, 16-18 April.

Price L, LeFever J. 1992. Does Bakken horizontal drilling imply a huge oil-resource base in fractured shales? In: Schmoker JW,
Coalson EB, Brown CA eds. Geological studies relevant to horizontal drilling : examples from Western North America. Rocky Mountains Association, pp. 199-214.

Rylander E, Singer P, Jiang T, McLin R, Sinclair S. 2013. NMR T2 Distributions in the Eagle Ford Shale: reflections on Pore Size. SPE Paper 164554; Unconventional Resources Conference, Woodlands, Texas, 10-12 April.

Vially R. 2015. Les hydrocarbures de roche-mère: l'exemple américain est-il exportable? Géologues 185: 34-39.

Zhang T, Sun X, Ruppel S. 2013. Hydrocarbon geochemistry and pore characterization of Bakken Formation and implications to oil migration and oil saturation. SDA from AAPG Annual Convention, Pittsburg.

Cite this article as: Blaizot M. 2017. Worldwide shale-oil reserves: towards a global approach based on the principles of Petroleum System and the Petroleum System Yield, Bull. Soc. géol. Fr. 188: 33. 